\title{
Methods for controlling natural regeneration of Japanese raisintree (Hovenia dulcis Thunb.) in Araucaria forest
}

\author{
Lucas Carvalho Costa, Alexandre Behling, Carlos Roberto Sanquetta, \\ Ana Paula Dalla Corte \& Francelo Mognon
}

Universidade Federal do Paraná, Av. Lothário Meissner, 900, Campus III, CEP 80210-170, Curitiba, Paraná.

Received on 24.VIII.2012

Accepted on 20.XI.2017

DOI 10.21826/2446-8231201772307

ABSTRACT - This study investigates methods for controlling Hovenia dulcis natural regeneration. The experiment was conducted in São João do Triunfo, PR, using randomized blocks with three treatments (control - A, root removal - B and base cut - C) and five replications. Number of seedlings, saplings and small trees were recorded at the beginning, 60, 120 and 180 days after treatment. A high number of seedlings were observed, but over time mortality became evident regardless of treatment. Root removal reduced the number of seedlings when compared to base cut. Root removal differed statistically from the control and base cut treatments. Base cut did not differ statistically from the control. Root system plays an important role in survival and regrowth of juveniles of the target species. Root removal prevents regrowth and survival based on natural regeneration. By its attributes, this species may be considered a relevant alien invasive tree in the Araucaria Forest.

Keywords: invasive species, Mixed Rain Forest, uva-do-japão

RESUMO - Métodos de controle da regeneração natural da espécie Uva do Japão (Honevia dulcis Thunb.) na Floresta de Araucária. O estudo teve como objetivo testar métodos de controle da regeneração natural da uva-do-Japão. O experimento foi em blocos ao acaso e foi conduzido em São João do Triunfo-PR, com três tratamentos (testemunha - A, arrancar com raiz - B e corte na base - C) e 5 repetições. Número de plântulas, varetas e varas, bem como, altura e diâmetro da base foram medidos aos 60, 120 e 180 dias da aplicação dos tratamentos. Observou-se inicialmente grande número de plântulas e baixa mortalidade, porém, com o passar do tempo, a mortalidade foi mais evidente. O tratamento B reduziu mais rapidamente o número de plântulas em relação ao A. No tratamento C o sistema radicular se manteve no solo e em atividade, demonstrando o seu grande poder de rebrota. O tratamento B impediu a rebrota, eliminando as plantas do local, constituindo-se na melhor forma de controle até o momento.

Palavras-chave: espécie invasora, floresta ombrófila mista, uva-do-japão

\section{INTRODUCTION}

The Japanese raisintree (Hovenia dulcis Thunb.) occurs naturally between $25^{\circ}$ and $41^{\circ} \mathrm{N}$ and $100^{\circ}$ and $142^{\circ} \mathrm{E}$ (Köller 1979; Schumacher et al. 2008). It is a native species in Asia prevalent throughout India and Japan. It was introduced in Nepal, India, Paraguay, Argentina and southern Brazil (Fowler et al. 1997). In Brazil, this plant is used for timber and windbreaks, but has also been widely used for the restoration of degraded land because it attracts wildlife (birds and mammals).

Seed dispersal is made by birds and small animals. The species has characteristics typical of a weed: abundant fruits, intense seed dispersal and seedling establishment, and fast growth. These characteristics enabled it to invade forests where it competes with native species for light, nutrients, space and disperser fauna (Horus Institute 2010).

The situation in many invaded areas and the lack of prevention policies caused a biological contamination, which is one of the major agents of global change by human action along with greenhouse effect and conversion of natural landscapes into agriculture fields. Moreover, the same species invades different countries and the dominant flora tends to exert a homogenizing effect on the world flora. Invasive exotic plants also tend to produce changes in essential ecological properties such as nutrient cycling, plant productivity, food webs, structure, dominance, distribution functions of species in a given ecosystem, biomass distribution, species density, vegetation size, accumulation of litter and biomass (thereby increasing risk of fire), decomposition rates, evolutionary processes and relations between pollinators and plants and, in general, impoverishment of ecosystems (Ziller 2000, 2001).

Although the control of this species is a major challenge for landowners and environmental institutions, virtually no work has been conducted on this subject. The objective of this study is to test ways of controling the natural regeneration of the species Hovenia dulcis Thunb., Japanese raisintree, in an Araucaria Forest in São João do Triunfo, Paraná state. 


\section{MATERIAL AND METHODS}

\section{Study Area}

The São João do Triunfo Experimental Station is located approximately $125 \mathrm{~km}$ from Curitiba at the coordinates $25^{\circ} 34^{\prime} 18^{\prime \prime} \mathrm{S}$ e $50^{\circ} 05^{\prime} 56^{\prime \prime} \mathrm{W}$, and $780 \mathrm{~m}$ a.s.l.

According to the Köppen climatic classification system, the climate at the experimental station is $\mathrm{Cfb}$, or mesothermal, humid with mild summers. Climate data Durigan (1999) obtained from IAPAR (Agronomic Institute of Paraná) weather stations near the study area reported that the average air temperature is $17.4^{\circ} \mathrm{C}$, the average relative humidity is $80.1 \%$, and the average rainfall is $1,615 \mathrm{~mm}$.

According to Longhi (1980), based on a survey conducted in the area, the predominant soil type is Dystrophic Red-Yellow Argissol as well as Alic Cambisol. Durigan (1999) conducted surveys and identified the occurrence of Dark Red and Red-Yellow Latosol as well as Inceptisols and Entisols. According to the classification proposed by the IBGE (1992) cited by Pizatto (1999), the dominant vegetation type in the study area is Araucaria Forest. Although this forest has not suffered clearcuts, some anthropogenic interventions have occurred in some parts of the experimental area (Schaaf 2001).

\section{Data Collection}

We tested two methods for controling Japanese raisintrees: base-cut and root removal. They were compared to a control with intervention that replicated the natural behavior of the species in that environment (Figs. 1A-C). The experiment was conducted in five replicates using a completely randomized design.

The base cut treatment involved cutting the stem of the plant at the base using pruning shears for young plants and a handsaw for larger individuals. The root removal treatment involved manually uprooting all individuals at the early stages of development, while more developed individuals were uprooted using tools (hoes and trench shovels), thus eliminating the root system of the plant. This procedure was used only at the beginning of the experiment.

Initially, 15 sites were designated for adult Japanese raisintrees (parent plants), each with a potential to later undergo a particular treatment by random selection. This randomized experimental design was conducted in five replicates. Each experimental unit had four square meters $(2 \mathrm{~m} \times 2 \mathrm{~m})$ in size, and was located near parent trees in a densely populated area undergoing a natural regeneration. Once the plots were delineated, treatments were assigned to each plot by random selection using the software ArcGIS 9.3.1 (Fig. 2).

To evaluate treatments, three categories of plants were chosen based on height. Individuals shorter than $0.30 \mathrm{~m}$ were called "seedlings", those between 0.30 and $1.30 \mathrm{~m}$ were called "stems", and taller than $1.30 \mathrm{~m}$ were called "saplings". All plants found in the plots were measured, plotted on the map sketch and identified with a numbered tag (except seedlings). To assess the number of seedlings, a
$0.25 \mathrm{~m}^{2}(0.5 \times 0.5 \mathrm{~m})$ area was delineated in the northwest corner of each plot. Individuals were counted, and the spatial location was also plotted on the map sketch. The location enabled a seedling count without requiring researchers to enter the plot itself, thus ensuring minimal interference in the natural development of seedlings and in the results of the study.

The experiment began in December 2010, which is considered time period zero. Subsequently, three assessments were conducted at intervals of 60 days (day 60, day 120 and day 180). Sapling height (in meters) and circumference at breast height $(\mathrm{CBH})$ were measured (in centimeters). Only the height of stems was recorded. Seedlings underwent a simple individual count. These measurements were carried out in every inventory.

\section{Data Analysis}

Field data obtained were subjected to statistical analysis using the software SAS (Statistical Analysis System) Learning Edition 8.0 (2003), with which the basic assumptions of the analysis of variance (normality) were tested to later perform analysis of variance and $\mathrm{F}$ test. When the factors of the control method were significant $(p<0.05)$, averages of each variable were then compared (root removal, base cut) to the control using a Dunnett's test at $5 \%$ probability. When the factor evaluation period was significant, variables were analyzed for their tendency by regression analysis. The $\mathrm{F}$ test indicated the degree of the polynomial equation to be used. When the interaction (control method * evaluation period) was significant, the effects were separated using a Tukey test at $5 \%$ probability. Based on the locations of each Japanese raisintree, thematic maps of spatial distribution of each sampling unit were produced using the software GIS ArcMap 9.3.1. The spatial distribution was designed to visually discern the behavior of the spatial distribution of the species before treatment (day zero) up to the final evaluation (180 days).

\section{RESULTS AND DISCUSSION}

The analysis of variance revealed significant differences between the control methods for the control of Japanese raisintrees in the following variables: stem number, sapling number, stem height and sapling height. During several periods in the assessment, significant differences were observed for seedling number, sapling number and sapling height. Only sapling number was significant for the interaction between control method and evaluation period (Table 1). The circumference at breast height was not significant for any factor studied.

At the time of the establishment of the experiment (time 0 ), the greatest densities of seedlings in all treatments were noticed (Fig. 3a). A decrease tendency in the number of seedlings was observed for all treatments over time (60, 120 and 180 days after the beginning of the experiment). The analysis of variance $(p<0.05)$ indicated that none of the treatments (methods of controlling seedlings) affected 

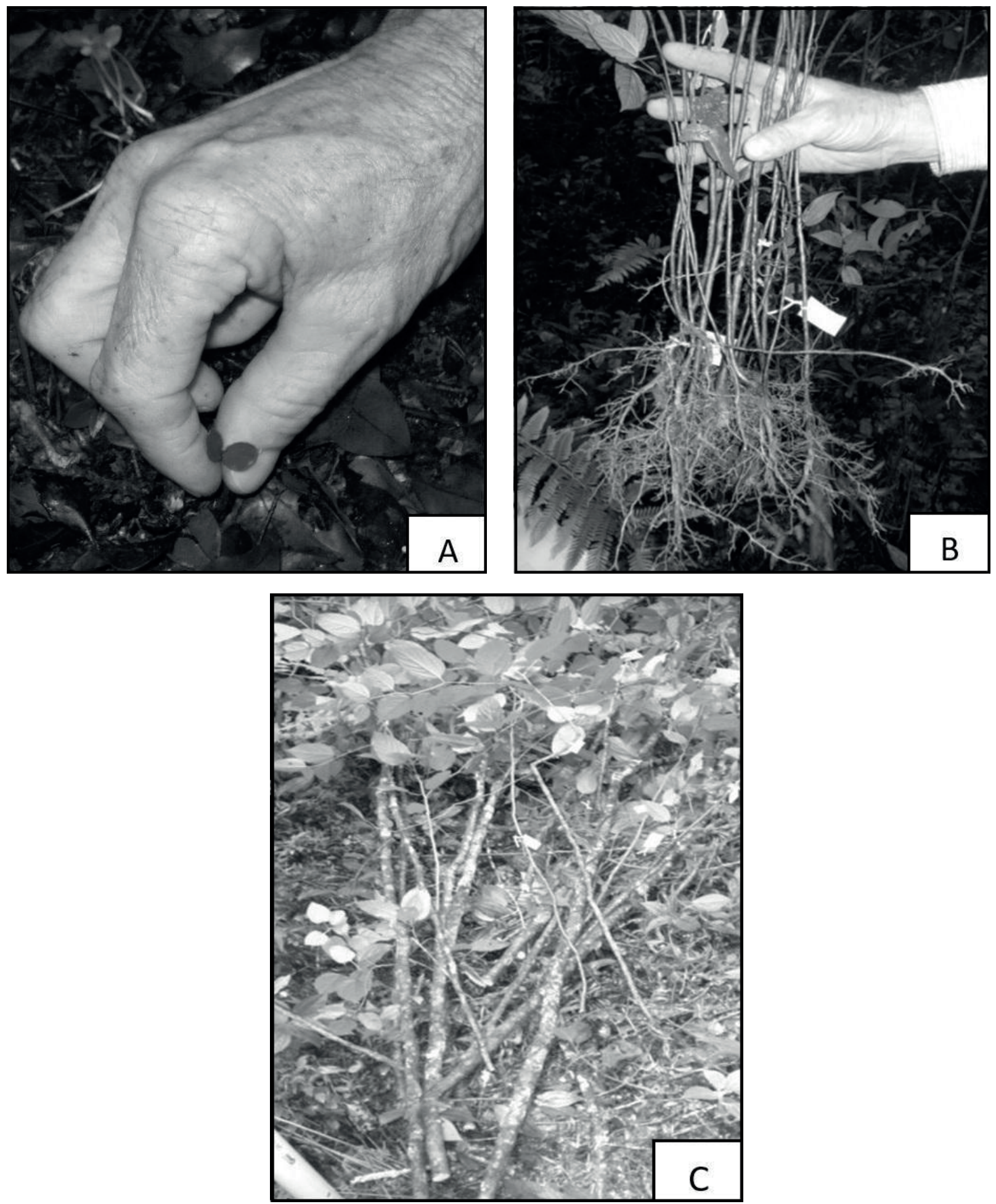

Figs. 1A-C. Application of three methods to control the natural regeneration of Japanese raisintrees. A. control; B. root removal; C. base cut in an Araucaria Forest in São João do Triunfo, Paraná.

seedling survival. In spite of this, it was found that seedling mortality was lower for the base cut treatment than for the other treatments, as can be seen in figure $3 \mathrm{~b}$. Mortality was greater 180 days after treatment application. Possibly, this happened because the root system of the seedlings was kept and, therefore, it may have facilitated seedling regrowth.
According to Sun et al. (1995), at the beginning of germination, the low moisture content and soil compaction jointly determined seedling establishment. Howe (1989), Loiselle (1990) and Pizo \& Simão (2001) reported that seedlings grown from clusters of seeds are subject to a greater intraspecific competition than isolated seeds. 


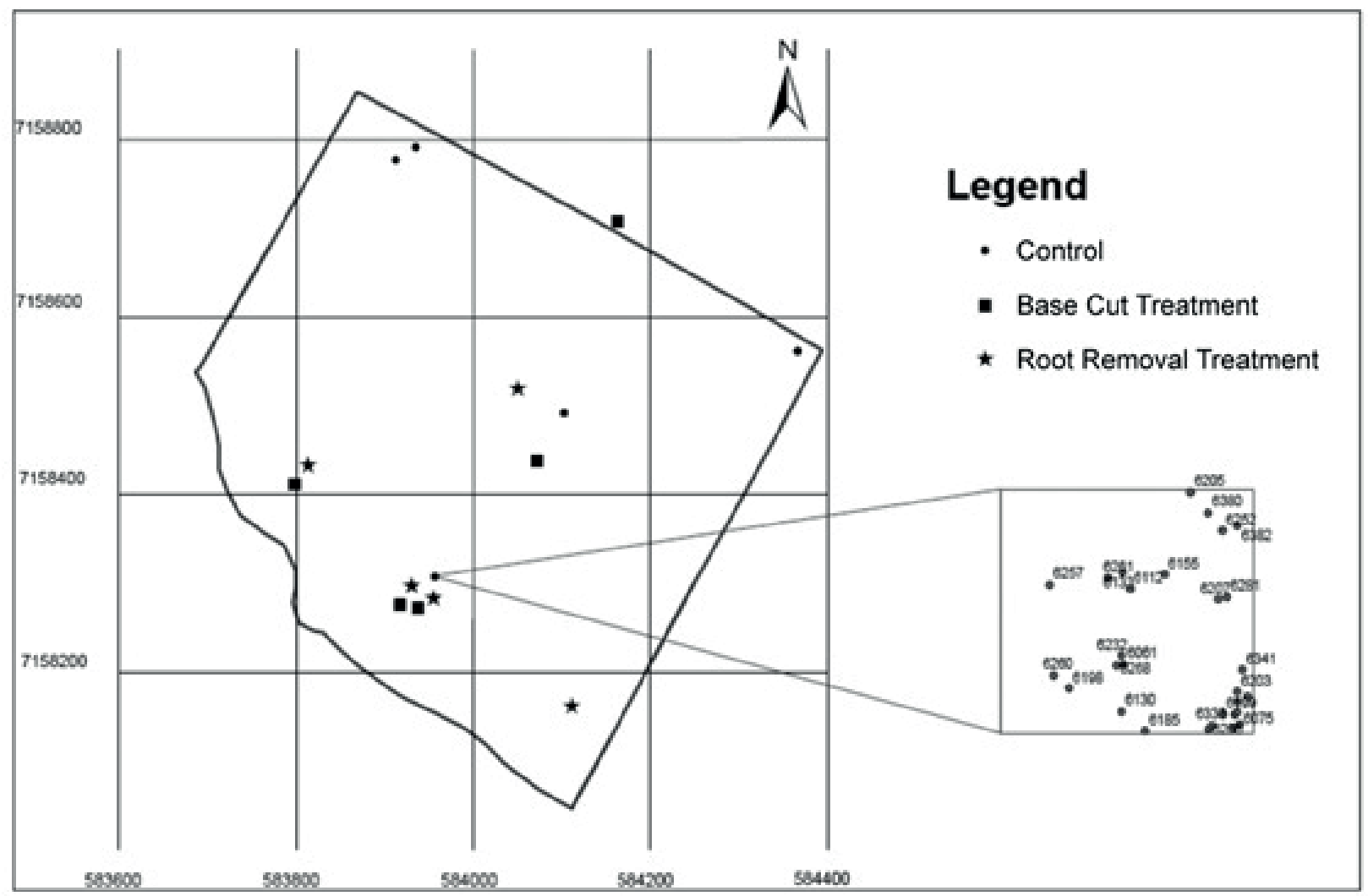

Fig. 2. Spatial distribution of the three tested methods for controlling Japanese raisintree: control ( $\bullet$ ), root removal ( $\star$ ) and base cut ( $\boldsymbol{\square}$ ), in an Araucaria Forest in the São João do Triunfo municipality, Paraná.

Table 1. Summary of analysis of variance for the variables seedling number, stem number, number of saplings, stem height, sapling height and circumference at breast height in function of control method for Japanese raisintrees: control, base cut and root removal at different evaluations periods $(0,60,120$, and 180 days after the application of the control method) in an Araucaria Forest in São João do Triunfo, Paraná. * = significant at $5 \%$ probability; $\mathrm{ns}=$ not significant at $5 \%$ probability.

\begin{tabular}{|c|c|c|c|c|c|c|c|}
\hline \multicolumn{8}{|c|}{ Primary Effect } \\
\hline \multirow[b]{2}{*}{ Factor } & \multirow[b]{2}{*}{$\begin{array}{l}\text { Degree of } \\
\text { Freedom }\end{array}$} & \multicolumn{6}{|c|}{ Mean Square } \\
\hline & & $\begin{array}{l}\text { Seedling } \\
\text { Number }\end{array}$ & $\begin{array}{l}\text { Stem } \\
\text { Number }\end{array}$ & $\begin{array}{l}\text { Sapling } \\
\text { Number }\end{array}$ & $\begin{array}{l}\text { Stem } \\
\text { Height }\end{array}$ & $\begin{array}{l}\text { Sapling } \\
\text { Height }\end{array}$ & $\begin{array}{c}\text { Sapling } \\
\text { Circumference } \\
\text { (Breast Height) }\end{array}$ \\
\hline Control Method & 2 & $1,457.079^{\mathrm{ns}}$ & $988.868^{*}$ & $305.121 *$ & $0.580^{*}$ & $14.311 *$ & $68.871^{\mathrm{ns}}$ \\
\hline Evaluation Period & 3 & $4,174.209 *$ & $126.389^{\text {ns }}$ & $38.777 *$ & $0.143^{\text {ns }}$ & $16.471 *$ & $43.968^{\text {ns }}$ \\
\hline Method * Period & 6 & $485.968^{\mathrm{ns}}$ & $110.437^{\mathrm{ns}}$ & $18.364 *$ & $0.087^{\mathrm{ns}}$ & $2.634^{\mathrm{ns}}$ & $12.84^{\text {ns }}$ \\
\hline Coefficient of Determination (\%) & & 36.05 & 35.09 & 46.34 & 33.56 & 45.3 & 21.60 \\
\hline Coefficient of Variation (\%) & & 147 & 88.21 & 107.9 & 55.14 & 97.4 & 158.04 \\
\hline \multicolumn{8}{|c|}{ Simple Effects } \\
\hline \multicolumn{8}{|c|}{ (Control Method * Evaluation Period) on Sapling Number } \\
\hline \multirow{3}{*}{ Method } & \multicolumn{2}{|c|}{ Control } & & \multicolumn{2}{|c|}{3} & \multicolumn{2}{|r|}{$5.5333^{\text {ns }}$} \\
\hline & \multicolumn{2}{|c|}{ Root Removal } & $\begin{array}{l}\text { Degree of } \\
\text { Freedom }\end{array}$ & \multicolumn{2}{|c|}{3} & \multicolumn{2}{|r|}{$22.05 *$} \\
\hline & \multicolumn{2}{|c|}{ Base Cut } & & \multicolumn{2}{|c|}{3} & \multicolumn{2}{|r|}{$48^{*}$} \\
\hline \multirow{4}{*}{ Period } & \multicolumn{2}{|c|}{0} & & \multicolumn{2}{|c|}{2} & \multicolumn{2}{|r|}{$37.2667^{*}$} \\
\hline & \multicolumn{2}{|c|}{60} & Degree of & \multicolumn{2}{|c|}{2} & \multicolumn{2}{|r|}{$9.2667^{\mathrm{ns}}$} \\
\hline & \multicolumn{2}{|c|}{120} & Freedom & \multicolumn{2}{|c|}{2} & \multicolumn{2}{|r|}{$11.2792^{\mathrm{ns}}$} \\
\hline & \multicolumn{2}{|c|}{180} & & \multicolumn{2}{|c|}{2} & \multicolumn{2}{|r|}{$27.8^{*}$} \\
\hline
\end{tabular}


At the beginning of the experiment, control plots had an average of 19 stems per plot $\left(4 \mathrm{~m}^{2}\right)$, but decreased to 14 at the first evaluation time. At the second evaluation time, this number decreased to 11.8 , and then to 13.8 at the third evaluation time. This decrease in the average number is due to individuals becoming saplings: 9 over all periods. 20 individuals died during the periods (Fig. 4b).

Regarding the base cut treatment, an average of 14 $\mathrm{m}^{2}$ per plot $\left(4 \mathrm{~m}^{2}\right)$ were found at the beginning of the experiment, decreasing to only 0.8 at the first evaluation period and 1.2 at the third evaluation period. The difference from other methods occurs in function of the efficiency of the treatment in eradicating the number of individual stems, preventing the dispersal of this species in the environment.

The base cut treatment resulted in an average of 13.6 stems per plot $\left(4 \mathrm{~m}^{2}\right)$ at the beginning of the experiment, 15 at the first evaluation time, 21 and 23.6 at the second and third evaluation times, respectively. In propagation studies using stakes, Carvalho (1994) considered the root system excellent because of the adundance of fibrous roots uniformly distributed around the stem, a fact verified in the present study. In this case, despite cutting the base, the entire root system remained fully active, demonstrating a vigor of the plants' regrowth behavior. We also observed that stumps of individuals with a circumferance between $2.5 \mathrm{~cm}$ and $5.00 \mathrm{~cm}$ bore 10 to 14 sprouts, an observation confirmed by the regrowth of plants distributed in a circular pattern around stumps. 15 individual stems which originated from seedlings were counted at all stages. However, they were not considered for stem survival percentage, as they were not produced as a direct result of the treatment.

A significant difference was also observed between the control methods for the variable stem height. According to the Dunnett's test, the root removal treatment resulted in individuals smaller than the individuals of the control treatment (Table 2). The application of this treatment prevented the development of new individuals, and hence height growth. The base cut treatment, which, despite the removal of the entire plant shoot, left the entire root system intact in the soil and fully active, demonstrating the plants' vigorous resprounting behavior and growth potential (Fig. 5).

Significant differences were observed among control methods, evaluation periods and their interactions (evaluation period * control method). The Dunnett test (Table 2) revealed a significant difference only between the control and the root removal treatment. This difference was due to the method's efficiency in eliminating individuals that could not resprout
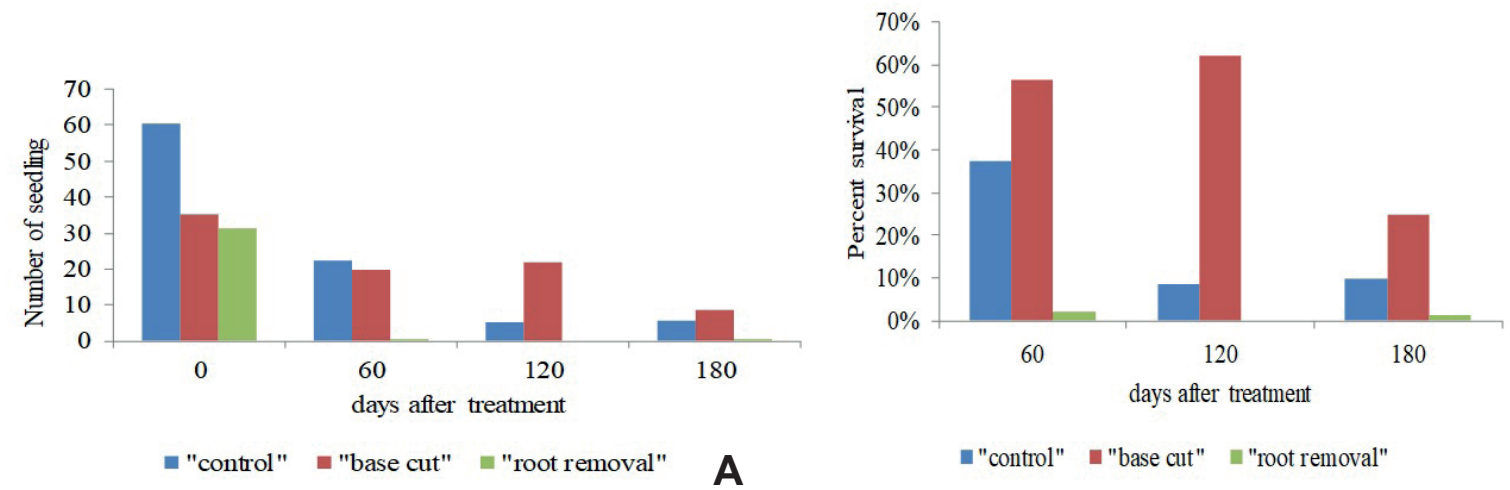

Figs. 3 A, B. Effects of Japanese raisintree control method on seedling number and percent survival for control, base cut and root removal treatments at different evaluation periods $(0,60,120$, and 180 days). Experiment conducted in an Araucaria Forest in São João do Triunfo, Paraná.
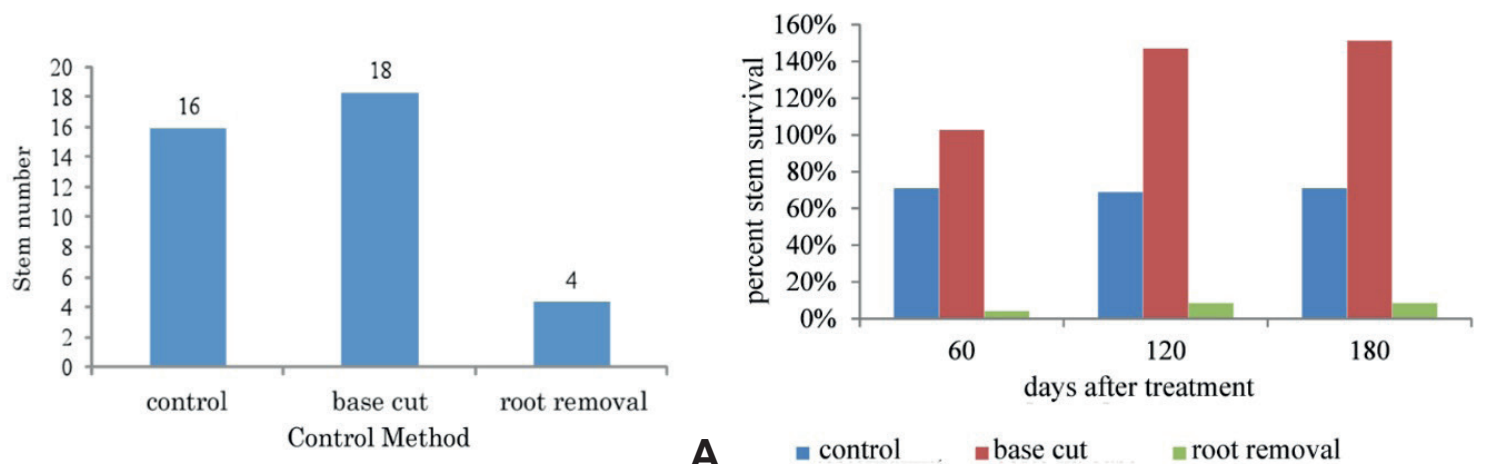

A

a control

-base cut

= root removal

Figs. 4 A, B. Effects of Japanese raisintree control method on stem number and survival regarding control, base cut and root removal treatments at different evaluation times $(0,60,120$, and 180 days). The study was conducted in an Araucaria Forest in São João do Triunfo, Paraná. 
(Fig. 6). In contrast, the base cut method allowed many large diameter individuals (up to 14 new individuals) to resprout. Some became stems and small trees.

The control plots $\left(4 \mathrm{~m}^{2}\right)$ began with an average of 11 saplings, 13 at the first evaluation time, and 15 and 17 in the second and third evaluation times, respectively. Of the original 11 saplings, 5 died and 9 grew into stems at the end of the third evaluation period.

Root removal treatment plots $\left(4 \mathrm{~m}^{2}\right)$ began with an average of 21 saplings. At the final evaluation period, no saplings remained.

Base cut treatment plots had an average of 38 individuals: 3 at the first evaluation time, and 6 and 16 at the second and third evaluation times, respectively. They originated by resprouting.

According to simple effects, only base cut and root removal treatments were significant (Table 1) in all evaluation periods. The root removal treatment was effective in extinguishing all sapling individuals. On the other hand, the base cut treatment, while effective in initially decreasing the number of individuals, allowed new individuals to appear by resprouting (Fig. 6).

For the interaction between control method and evaluation period, significant differences were observed only between the times zero and 180 days after treatment application according to simple effects (Table 1). According to the Tukey test (Table 3), although the base cut and root removal methods showed the highest sapling numbers

Table 2. Dunnett's average test applied to stem number, stem height, sapling number and sapling height in function of the control method for controlling Japanese raisintrees (control, base cut and root removal) in an Araucaria Forest in São João do Triunfo, Paraná.

\begin{tabular}{lccc}
\hline & & \multicolumn{2}{c}{ Minimum significant difference between averages } \\
Treatment-Control Comparison & Stem Number & Sapling Number & Stem Height \\
Base Cut - Control & $-11.6 \mathrm{~ns}$ & $-0.0369 \mathrm{~ns}$ & $0.1895 \mathrm{~ns}$ \\
Root Removal - Control & $-1.205^{*}$ & $-0.3125 *$ & $-2.05 *$ \\
\hline
\end{tabular}

$+=$ Significant and greater than control by Dunnett's Test at 5\% probability;- = Significant and lower than control by Dunnett's Test at 5\% probability; ns $=$ Not significant by Dunnett's Test at $5 \%$ probability.

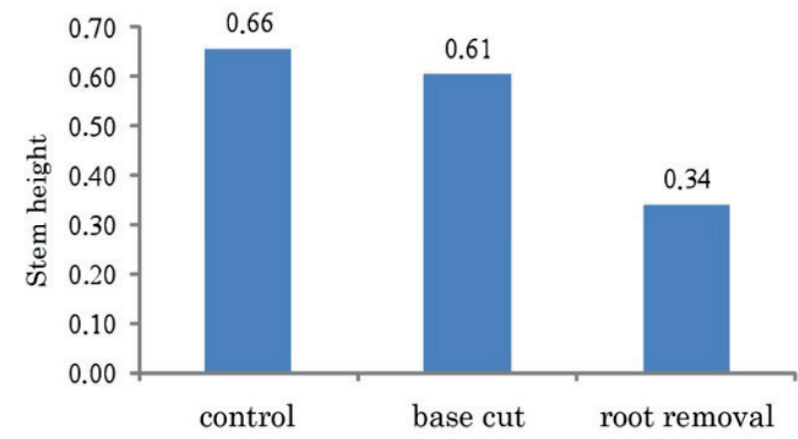

Control Method

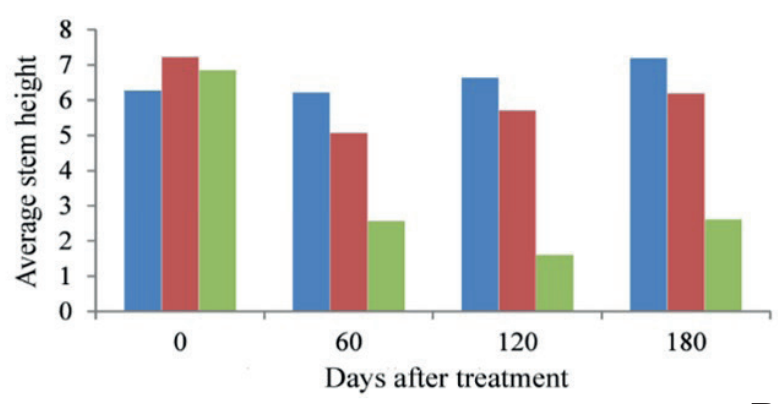

control

Figs. 5 A, B. Effects of Japanese raisintree control method on stem height regarding control, base cut and root removal in treatments at different evaluation times $(0,60,120$, and 180 days). The study was conducted in an Araucaria Forest in São João do Triunfo, Paraná.

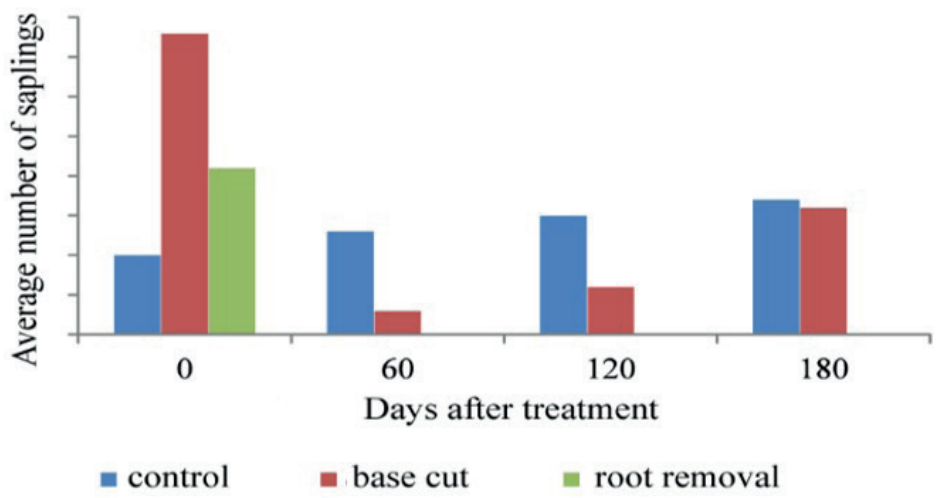

Fig. 6. Average number of saplings after the application of Japanese raisintree control methods control, base cut and root removal in treatments at different evaluation periods $(0,60,120$, and 180 days). The study was conducted in an Araucaria Forest in São João do Triunfo, Paraná. 
Table 3. Comparison of effects of control method on sapling numbers by Tukey test regarding control, base cut and root removal averages in treatments at different evaluation periods $(0,60,120$, and 180 days after the application of the control method) in an Araucaria Forest in São João do Triunfo, Paraná.

\begin{tabular}{lccc}
\hline Control Method & \multicolumn{3}{c}{ Period (Days after application of the control method) } \\
& 0 & 60 & 120 \\
\hline Control & $2.20 \mathrm{~b}$ & $2.60 \mathrm{~ns}$ & $3.00 \mathrm{~ns}$ \\
Base Cut & $7.60 \mathrm{a}$ & $0.60 \mathrm{~ns}$ & $1.36 \mathrm{~ns}$ \\
Root Removal & $4.20 \mathrm{ab}$ & $0 \mathrm{~ns}$ & $3.20 \mathrm{ab}$ \\
\hline
\end{tabular}

Letters indicate significant differences for $\mathrm{p}<0.05$.
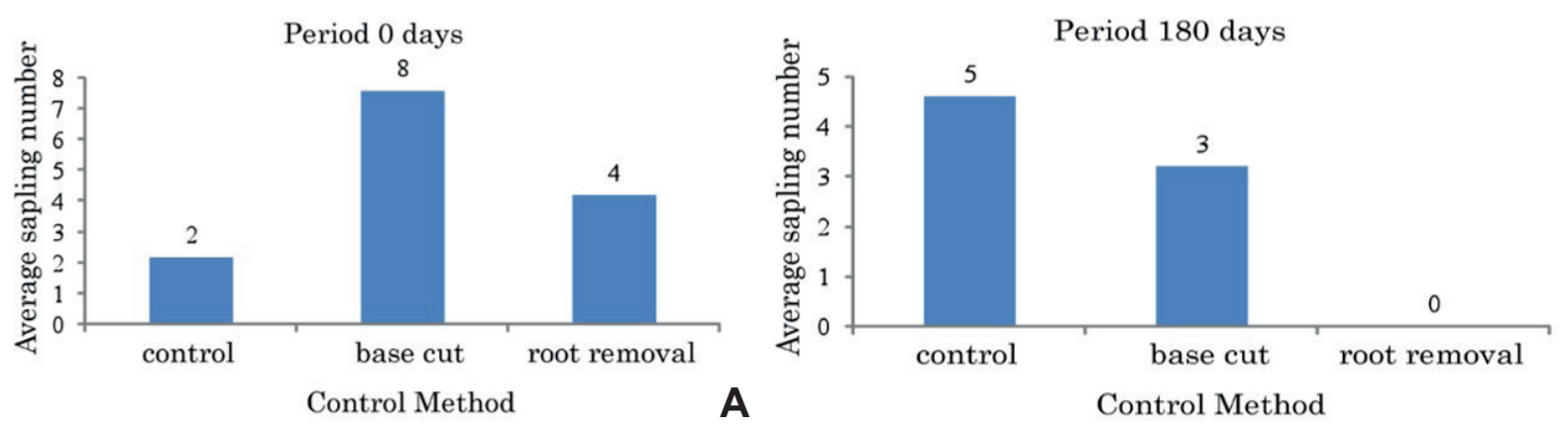

Figs. 7 A, B. Effects of Japanese raisintree control method on sapling numbers regarding control, base cut and root removal treatments at different evaluation periods $(0,60,120$, and 180 days after the application of the control method) in an Araucaria Forest in São João do Triunfo, Paraná.

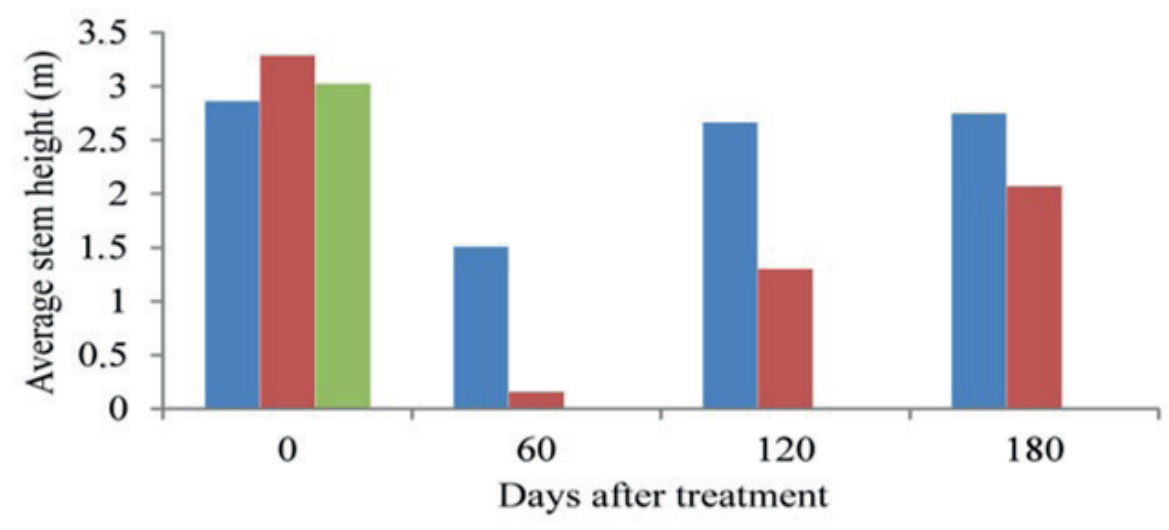

=Control $\quad$ Base Cut $\quad$ Root Removal

Fig. 8. Average height of saplings after application of Japanese raisintree control methods control, base cut and root removal in treatments at different evaluation periods $(0,60,120$, and 180 days after the application of the control method) in an Araucaria Forest in São João do Triunfo, Paraná.

at time zero, this relation reversed after 180 days, i.e., control plots had a higher number of saplings. The root removal method proved effective for the local eradication of individuals. Saplings were absent from the plots at the final evaluation time (Fig. 7).

For the variable sapling height, control method and evaluation period proved significant. According to the Dunnett test, the root removal treatment had results lower than the control (Table 2). As already mentioned, this result is likely the result of the treatment's efficiency in locally eradicating individuals. With respect to the period, there was an initial reduction in height due to the entry of new individuals from smaller height classes in the base cut or control plots. However, the development of these individuals was normal (Fig. 8). 
A fact that should be highlighted is the occurrence of the Japanese raisintrees in the region of the study area. This can be found in Schaaf et al. (2006). These authors pointed out that this species was not detected in 1979, and in few years since 2000 it has overrun many native species, an evidence for its aggressiveness as an invasive species.

Japanese raisintrees were probably brought to this area by birds, which are highly attracted to their fruits, and several likely sources exist on the properties near the area analyzed. The success in competing with native species is probably due to the absence of natural predators and/ or competitors with which it co-evolved. In this study, satisfactory results were achieved for controling this species using the root removal method Schaaf et al. (2006). However, we emphasize the need for studies that evaluate the costs involved in this method.

For sintese, seedling mortality occurs naturally, independent of control method. However, some individuals remain in the environment, grow and develop. The base cut method does not affect the survival of a large proportion of individuals of this species. Rather, they are highly resistant in the local environment and resprout even after the control measure was applied. On the other hand the root removal method is effective in preventing regrowth, locally eliminating plants, and represents the most effective means for controling this species.

\section{REFERENCES}

Carvalho, P.E.R. 1994. Ecologia, Silvicultura e Usos da Uva-doJapão (Hovenia dulcis Thunberg). Empresa Brasileira de Pesquisa Agropecuária. 24p.

Durigan, M.E. 1999. Florística, dinâmica e análise protéica de uma Floresta Ombrófila Mista em São João do Triunfo - PR. Dissertação
125 f., Universidade Federal do Paraná, Curitiba.

Fowler, J.A.P., Zanon, A. \& Carpanezzi, A.A. 1997. Conservação de sementes de uva-do-japão (Hovenia dulcis Thunberg): relação entre a viabilidade e a coloração. Boletim de Pesquisa Florestal 35(1):67-73.

Howe, H.F. 1989. Scatter and clump-dispersal and seedling demography: hypothesis and implications. Oecologia 79(1):417-426.

Horus Institute. 2010. Uva-do-japão (Hovenia dulcis Thumb). Disponível em: http://www.institutohorus.org.br. Acessado em 07 Jun 2010.

Koller, G.L. 1979. The Raisin tree - it's use, hardiness and size. Arnoldia 39(1):7-15.

Loiselle, B.A. 1990. Seeds in droppings of tropical fruiteating birds: importance of considering seed composition. Oecologia 82(1):404-500.

Longhi, S.J. 1980. A estrutura de uma floresta natural de Araucaria angustifolia (Bert.) O. Ktze, no sul do Brasil. Dissertação 198 f., Universidade Federal do Paraná, Curitiba.

Pizatto, W. 1999. Avaliação biométrica da estrutura e da dinâmica de uma Floresta Ombrófila Mista em São João do Triunfo - PR. Dissertação 172 f., Universidade Federal do Paraná. Curitiba.

Pizo, M.A. \& Simão, I. 2001. Seed deposition patterns and the survival of seeds and seedlings of the palm Euterpe edulis. Acta Oecologia 22(1):229-233.

Schaaf, L.B., Figueiredo Filho, A., Galvão, F., Sanquetta, C.R. \& Longhi, S.J. 2006. Modificações florístico-estruturais de um remanescente de floresta Ombrófila Mista Montana no período entre 1979 e 2000. Ciência Florestal 16(3):271-291.

Schaaf, L.B. 2001. Florística, estrutura e dinâmica no período 1979-2000 de uma floresta ombrófila mista localizada no Sul do Paraná. Curitiba. Dissertação 131 f., Universidade Federal do Paraná, Curitiba.

Schumacher, M.V., Brun, E.J., Illana, V.B., Dissiuta, S.I., Agne, T.L. 2008. Biomassa e nutriente em um povoamento de Hovenia dulcis Thumb., plantado na FEPAGRO. Ciência Florestal 18(1):27-37.

Sun, D., Dickinson, G.R. \& Bragg, A.L. 1995. Direct seeding of Alphitonia petriei (Rhamnaceae) for gully revegetation in tropical northern Australia. Forest Ecology and Management 73(1):249-257.

Ziller, S.R.A. 2000. Estepe-Gramíneo Lenhosa no Segundo Planalto do Paraná: Diagnóstico Ambiental com Enfoque à Contaminação Biológica. Tese 268 f., Universidade Federal do Paraná, Curitiba. . 2001. Os processos de degradação ambiental originados por plantas exóticas invasoras. Revista Ciência Hoje, Coluna Opinião 30(178):1-6. 